\title{
STRUCK BY STEREOTYPE: RUTH BADER GINSBURG ON PREGNANCY DISCRIMINATION AS SEX DISCRIMINATION
}

\author{
NEIL S. SIEGEL $\dagger$ \\ REVA B. SIEGEL $\dagger \dagger$
}

It was always recognition that one thing that conspicuously distinguishes women from men is that only women become pregnant; and if you subject a woman to disadvantageous treatment on the basis of her pregnant status, which was what was happening to Captain Struck, you would be denying her equal treatment under the law. ${ }^{1}$

\section{INTRODUCTION}

This is an attempt at recovery. This Essay hopes to call attention to then-Professor Ruth Bader Ginsburg's 1972 merits brief $^{2}$ in Struck v. Secretary of Defense. ${ }^{3}$ The brief has been underappreciated in part because the Supreme Court of the United States eventually declined

Copyright (C) 2010 by Neil S. Siegel \& Reva B. Siegel.

$\dagger$ Professor of Law and Political Science, Duke University School of Law; Law Clerk to Justice Ginsburg, October Term 2003.

$\dagger \dagger$ Nicholas deB. Katzenbach Professor of Law, Yale Law School. We thank Associate Justice Ruth Bader Ginsburg for illuminating comments on this Essay, and Natalie Bedoya and Jennifer Bennett for able research assistance.

1. Nomination of Ruth Bader Ginsburg to Be Associate Justice of the Supreme Court of the United States: Hearing Before the S. Comm. on the Judiciary, 103d Cong. 206 (1993) (statement of Judge Ginsburg) [hereinafter Ginsburg Hearings].

2. See Brief for the Petitioner, Struck v. Sec'y of Def., 409 U.S. 1071 (1972) (No. 72-178), 1972 WL 135840. Melvin Wulf, Joel Gora, Brenda Feigen Fasteau, and Robert Czeisler also signed the brief. Melvin Wulf was the Legal Director of the American Civil Liberties Union (ACLU). Joel Gora was an ACLU attorney who worked on the case. Brenda Feigen (no longer Fasteau) was a cofounder of the ACLU's Women's Rights Project. Robert Czeisler was the attorney, affiliated with the ACLU in the state of Washington, who represented Captain Struck in the district court and the Ninth Circuit. His valiant lawyering kept Captain Struck in the Air Force and fighting to remain there, not discharged, as the government would have preferred. It is evident that Ginsburg's distinctive voice pervades the brief.

3. Struck v. Sec'y of Def., 409 U.S. 1071 (1972). 
to decide the case. ${ }^{4}$ But anyone seeking to understand the origins and nature of Justice Ginsburg's views on sex discrimination would be well advised to read this brief. So would anyone interested in reimagining the bounds of constitutional possibility in the realm of gender equality.

In her capacity as general counsel for the Women's Rights Project of the American Civil Liberties Union, Ginsburg filed the Struck brief a little more than a year after the Court decided Reed $v$. Reed, ${ }^{5}$ but before the Court began to give shape to liberty and equality doctrine concerning the regulation of pregnant women in cases such as Roe v. Wade, ${ }^{6}$ Frontiero v. Richardson, ${ }^{7}$ and Geduldig v. Aiello. ${ }^{8}$ Ginsburg wrote the brief on behalf of an Air Force officer, Captain Susan Struck, whose pregnancy-and whose refusal on

4. See id. at 1071 (vacating and remanding for consideration of mootness in light of the government's change in position).

5. Reed v. Reed, 404 U.S. 71 (1971). Reed invalidated under the Equal Protection Clause an Idaho law that gave automatic preference to men over women as administrators of estates. Id. at 77. Reed was handed down on November 22, 1971. The Struck brief was filed on December 4, 1972.

6. Roe v. Wade, 410 U.S. 113 (1973). The Court decided Roe on January 22, 1973, less than two months after Ginsburg filed the Struck brief.

7. Frontiero v. Richardson, 411 U.S. 677 (1973). Frontiero invalidated under the Equal Protection Clause a federal statute providing that spouses of male members of the military are dependents for purposes of obtaining increased quarters allowances and medical and dental benefits, but that spouses of female members are not dependents unless they are in fact dependent for more than one-half of their support. Id. at 692 (plurality opinion).

8. Geduldig v. Aiello, 417 U.S. 484 (1974). Geduldig upheld against an equal protection challenge a California law that provided workers comprehensive disability insurance for all temporarily disabling conditions that might prevent them from working, except pregnancy, on the ground that pregnancy discrimination was not necessarily sex discrimination. Id. at 496-97. Although laws burdening pregnant employees harm only female employees, the Court stressed that they potentially benefit a group that includes employees of both sexes. See id. at 497 n.20 ("The lack of identity between the excluded disability and gender as such under this insurance program becomes clear upon the most cursory analysis. The program divides potential recipients into two groups-pregnant women and nonpregnant persons. While the first group is exclusively female, the second includes members of both sexes. The fiscal and actuarial benefits of the program thus accrue to members of both sexes."). The Court subsequently tried to apply Geduldig's reasoning to federal employment discrimination law in General Electric Corp. v. Gilbert, 429 U.S. 125 (1976). Gilbert held that a disability benefit plan excluding disabilities related to pregnancy was not sex-based discrimination within the meaning of Title VII of the Civil Rights Act of 1964, 42 U.S.C. $\$ 2000$ e to e-17 (2006). Id. at 145-46. Congress responded by enacting the Pregnancy Discrimination Amendment to Title VII (PDA), which defines discrimination on the basis of pregnancy as discrimination on the basis of sex. See Pregnancy Discrimination Act, 42 U.S.C. § 2000e(k). 
religious grounds to have an abortion ${ }^{9}$ - subjected her to automatic discharge from military service. ${ }^{10}$

The brief demonstrates that, from the very beginning, Justice Ginsburg has conceived discrimination against pregnant women as a core case of sex discrimination. In 1972, Ginsburg understood pregnancy discrimination as sex discrimination because she has long viewed laws enforcing sex roles of the separate spheres tradition as compromising the "equal citizenship stature" of women."

In Struck, Ginsburg argued that excluding a pregnant woman from the Air Force when men otherwise similarly situated in their capacity or incapacity to work are provided sick leave is a core case of sex discrimination because the distinction "reflects arbitrary notions of woman's place wholly at odds with contemporary legislative and judicial recognition that individual potential must not be restrained, nor equal opportunity limited, by law-sanctioned stereotypical prejudgments." ${ }^{12}$ The brief opened by emphasizing that laws imposing traditional sex roles on pregnant women deny individuals equal opportunity and perpetuate the secondary social status of women:

Heading the list of arbitrary barriers that have plagued women seeking equal opportunity is disadvantaged treatment based on their unique childbearing function. Until very recent years, jurists have regarded any discrimination in the treatment of pregnant women and mothers as "benignly in their favor." But in fact, restrictive rules, and particularly discharge for pregnancy rules, operate as "built-in headwinds" that drastically curtail women's opportunities. Decisions of this Court that span a century have contributed to this anomaly: presumably well-meaning exaltation of woman's unique

9. Brief for the Petitioner, supra note 2, at 10-11.

10. Id. at 4 .

11. Justice Ginsburg has used this or similar language in a variety of settings, both on and off the Court. See, e.g., Gonzales v. Carhart, 127 S. Ct. 1610, 1641 (2007) (Ginsburg, J., dissenting) ("[L]egal challenges to undue restrictions on abortion procedures do not seek to vindicate some generalized notion of privacy; rather, they center on a woman's autonomy to determine her life's course, and thus to enjoy equal citizenship stature."); United States v. Virginia (VMI), 518 U.S. 515, 532 (1996) ("[T]he Court has repeatedly recognized that neither federal nor state government acts compatibly with the equal protection principle when a law or official policy denies to women, simply because they are women, full citizenship stature-equal opportunity to aspire, achieve, participate in and contribute to society based on their individual talents and capacities."). See generally Neil S. Siegel, Equal Citizenship Stature: Justice Ginsburg's Constitutional Vision in President Obama's America, 43 NEW ENG. L. REV. (forthcoming December 2009) (participating in a symposium honoring the jurisprudence of Justice Ginsburg).

12. Brief for the Petitioner, supra note 2 , at 7. 
role in bearing children has, in effect, restrained women from developing their individual talents and capacities and has impelled them to accept a dependent, subordinate status in society. ${ }^{13}$

Ginsburg thus argued that traditions of regulating women during pregnancy are not in fact benign but instead play a key role in imposing on women "subordinate" social status.

As this Essay shows, Ginsburg's equal protection argument in Struck anticipates views that she would subsequently express on the bench ${ }^{14}$-including her account of intermediate scrutiny for the Court in United States v. Virginia, ${ }^{15}$ which requires the judiciary closely to examine laws that classify on the basis of sex but allows government to differentiate between men and women so long as "such classifications [are] not...used, as they once were, to create or perpetuate the legal, social, and economic inferiority of women."16 The Struck brief illustrates beautifully how Ginsburg reasons from antisubordination values in defining constitutional equality, in identifying the perspective from which to determine whether equality values are implicated, and in linking equality- and liberty-based arguments for the full participation of women in the public and private life of the nation.

Ginsburg's understanding of pregnancy discrimination in Struck calls into question certain feminist characterizations of her as a

13. Id. at 9 (emphasis added) (quoting United States ex rel. Robinson v. York, 281 F. Supp. 8, 19 (D. Conn. 1968); Griggs v. Duke Power Co., 401 U.S. 424, 432 (1971)).

14. For one account of Ginsburg's legal strategy, see Deborah L. Markowitz, In Pursuit of Equality: One Woman's Work to Change the Law, 11 WOMEN's RTS. L. REP. 73 (1989). For examples of other feminist lawyers of the era who challenged pregnancy discrimination as sex discrimination, see Reva B. Siegel, Constitutional Culture, Social Movement Conflict and Constitutional Change: The Case of the De Facto ERA, 94 CAL. L. REV. 1323, 1385-86 (2006). "In constitutional and Title VII litigation in the early 1970s, feminist lawyers including Ruth Ginsburg, Wendy Williams, and Susan Deller Ross ... argu[ed] that regulations pertaining to pregnant women were sex-based, subject to heightened scrutiny, and wrongful when they enforced stereotypical understandings of women's roles." Id. Wendy Williams wrote the petitioner's brief in Geduldig, and Susan Deller Ross was pivotal "in providing arguments to the EEOC that the Equal Protection Clause reached pregnancy discrimination." Id. at 1385 n.169. Ruth Bader Ginsburg and Susan Deller Ross coauthored a 1977 op-ed responding to Geduldig. See Ruth Bader Ginsburg \& Susan Deller Ross, Pregnancy and Discrimination, N.Y. TiMES, Jan. 25, 1977, at A33 ("The Supreme Court decision was a stunning rejection of the position that had been taken by the Federal Equal Employment Opportunity Commission and six Federal courts of appeals. These authorities had identified discrimination against the pregnant worker as the essence of sex discrimination.").

15. United States v. Virginia (VMI), 518 U.S. 515 (1996).

16. Id. at 534 (citing Goesaert v. Cleary, 335 U.S. 464, 467 (1948)). 
proponent of formal equality - a criticism that has been advanced by those who viewed Ginsburg's repeated representation of male plaintiffs in the early sex discrimination cases as narrowly reflecting a concern with arbitrary sex-based classification only. ${ }^{17}$ Ginsburg argued that laws differentiating on the basis of sex are unconstitutional when they enforce traditional sex stereotypes because such laws wrongfully restrict individual opportunity and contribute to the subordinate status of women. Ginsburg was able to perceive social subordination in the exclusion of a pregnant woman from military service, even though pregnancy had long been understood as the principal physical difference between the sexes, because she saw that government regulation was enforcing traditional sex stereotypes. ${ }^{18}$ Ginsburg saw clearly.

As interesting and consequential as Ginsburg's own views have been, recovery of the Struck brief is even more important for what it illuminates about the present. In the immediate aftermath of Struck, the Court acknowledged that pregnancy discrimination might be an invidious expression of sex discrimination but did not seriously consider the account that Ginsburg and other feminist litigators offered of how laws discriminating against pregnant women could enforce traditional sex stereotypes and so deny women the equal protection of the laws. ${ }^{19}$ Nor did the Court scrutinize the relationship to which the Struck brief pointed-between cases protecting women's right to equal protection and protecting their autonomy in deciding whether to bear children. ${ }^{20}$ Decades later, however, through a series of incremental changes that have not yet been fully recognized, ${ }^{21}$ the Court has begun to reason from something like Ginsburg's position

17. See, e.g., Judith Baer, Advocate on the Court: Ruth Bader Ginsburg and the Limits of Formal Equality, in REHNQuist Justice: UndERSTANDING THE COURT DYNAMIC 216, 231 (Earl M. Maltz ed., 2003); see also infra note 84 and accompanying text. See infra Part III for a discussion of substantive (that is, antisubordination) versus formal (that is, anticlassification) views of equality.

18. Brief for the Petitioner, supra note 2, at 8-9.

19. See Geduldig v. Aiello, 417 U.S. 484, 496-97 n.20 (1974) ("Absent a showing that distinctions involving pregnancy are mere pretexts designed to effect an invidious discrimination against the members of one sex or the other, lawmakers are constitutionally free to include or exclude pregnancy from the coverage of legislation such as this on any reasonable basis, just as with respect to any other physical condition."). On feminist arguments of the era, see supra note 14.

20. See Brief for the Petitioner, supra note 2, at 10.

21. See infra Part IV (discussing changes manifest in decades of PDA litigation, Nevada Department of Human Resources v. Hibbs, 538 U.S. 721 (2003), and Planned Parenthood of Southeastern Pennsylvania v. Casey, 505 U.S. 833 (1992)). 
without quite embracing it. The final chapter in this domain of constitutional law has yet to be written.

Part I recounts the facts of Struck. Part II details the arguments Ginsburg made in her merits brief in the case. Part III explores what Struck suggests about Ginsburg's views on constitutional equality. Part IV shows that although the Court did not initially embrace the understanding of pregnancy discrimination that Ginsburg expressed in Struck, over time the Court has begun to internalize the feminist movement's concerns about the stereotyping pregnant women face, incorporating these concerns into equal protection and due process doctrines regarding the regulation of pregnant women.

\section{THE FACTS OF STRUCK}

The facts of Struck v. Secretary of Defense were straightforward. ${ }^{22}$ Captain Susan Struck was a career officer in the United States Air Force who served as a nurse in the Vietnam War. ${ }^{23}$ In 1970, she became pregnant. ${ }^{24}$ She was ordered to an Air Force base in the state of Washington, where a disposition board hearing was held. ${ }^{25}$ She declared her intent to give the child up for adoption as soon as she gave birth, and she stated that her accrued leave time of sixty days was more than sufficient to cover the temporary period of disability that she anticipated at the time of childbirth. ${ }^{26}$ The Air Force, however, pursuant to a regulation then in effect, gave her this choice: have an abortion on the base or leave the Service. ${ }^{27}$ Because Captain

22. This Essay takes the facts from the Brief for the Petitioner, supra note 2, at 3-7. Justice Ginsburg has recounted the story of Struck on more than one occasion. See Ruth Bader Ginsburg, Remarks for the Celebration of 75 Years of Women's Enrollment at Columbia Law School, 102 COLUM. L. REV. 1441, 1447 (2002); Ruth Bader Ginsburg, Speaking in a Judicial Voice, 67 N.Y.U. L. REV. 1185, 1200-02 (1992) (Madison Lecture delivered in March 1993); Ruth Bader Ginsburg, Assoc. Justice, Supreme Court of the U.S., Advocating the Elimination of Gender-Based Discrimination: The 1970s New Look at the Equality Principle, Address at the University of Cape Town, South Africa (Feb. 10, 2006) [hereinafter Ginsburg, Advocating], available at http://www.supremecourtus.gov/publicinfo/speeches/sp_02-10-06.html. She also discussed Struck at her Supreme Court confirmation hearing. See, e.g., Ginsburg Hearings, supra note 1, at 205-06; see also infra Part II.

23. Brief for the Petitioner, supra note 2, at 3.

24. Id.

25. Id. at $3-4$.

26. Id. at 4 .

27. See id. The regulation stated:

The commission of any woman officer will be terminated with the least practical delay when it is determined that one of the conditions in a or b below exist ...

a. Pregnancy: 
Struck was a practicing Roman Catholic, abortion was not an option for her. ${ }^{28}$ But neither did she quietly accept the termination of her chosen career. ${ }^{29}$ She instead sued to fend off the discharge, securing able representation from lawyers for the American Civil Liberties Union in Washington.

Captain Struck was able to obtain a stay of her discharge each month, but she lost on the merits both in the district court and in the United States Court of Appeals for the Ninth Circuit. ${ }^{30}$ In the view of those courts, it was constitutionally irrelevant that no other physical condition occasioning a temporary period of disability-whether a broken leg or drug and alcohol abuse (which might not be temporary) - resulted in mandatory discharge regardless of individual circumstances. ${ }^{31}$ Nor did it matter that a male officer who participated in conceiving a child was free-indeed, encouraged - to continue his service career as a parent. ${ }^{32}$

The Supreme Court agreed to entertain Captain Struck's claims to constitutional attention. Ginsburg scored the Air Force regulation at bar as a violation of (1) equal protection, (2) Captain Struck's right to privacy in the conduct of her personal life, and (3) her free exercise of religion. ${ }^{33}$ Solicitor General Erwin Griswold was apparently

\section{(1) General:}

(a) A woman will be discharged from the service with the least practical delay when a determination is made by a medical officer that she is pregnant.

...

b. Minor Children:

(1) General. The commission of any woman officer will be terminated with the least practical delay when it is established that she:

.

(d) Has given birth to a living child while in a commissioned officer status.

Struck v. Sec'y of Def., 460 F.2d 1372, 1374 (9th Cir. 1971) (quoting Air Force Regulation 3612). A 1971 amendment to the regulation provided that "Discharge Action will be cancelled if Pregnancy is Terminated." Id. at 1376 (quoting Part I.C of 1971 Amendments to Regulations).

28. Brief for the Petitioner, supra note 2, at 56.

29. See id. at 4.

30. Struck, 460 F.2d at $1374,1377$.

31. "[Captain] Struck's problem," Ginsburg fought the temptation to state in opening the brief, was that she "picked the wrong form of recreation in Vietnam." See Markowitz, supra note 14, at 81 n.100 (quoting oral statement by Ginsburg). Ginsburg held her tongue, id. at 81, presumably because she was concerned about turning off the audience.

32. See, e.g., Brief for the Petitioner, supra note 2, at 55 ("[P]arenthood among servicemen is not deterred, indeed additional benefits are provided to encourage men who become fathers to remain in service." (citations omitted)).

33. See infra Part II. 
concerned about the government's chances before the Court. "He recommended that the Air Force waive Captain Struck's discharge and abandon its policy of automatically discharging women for pregnancy." ${ }^{34}$ The Air Force agreed, and General Griswold moved to dismiss the case as moot. ${ }^{35}$

The Supreme Court never heard oral argument. It elected to vacate the judgment and remand the case to the Ninth Circuit "to consider the issue of mootness in light of the position presently asserted by the Government." ${ }^{36}$

\section{GINSBURG'S ARGUMENTS IN STRUCK}

Ginsburg's Struck brief has been neglected ${ }^{37}$ not only because the Court did not decide the merits of the case, but also because, shortly thereafter, the Justices rejected an equal protection challenge to a pregnancy discrimination claim. ${ }^{38}$ This neglect is unfortunate. Among its other virtues, the Struck brief clarifies Justice Ginsburg's approach to sex discrimination. Recalling Captain Susan Struck's story during her Supreme Court confirmation hearing, then-Judge Ginsburg sought "to explain how [her] own thinking developed on [the] issue" of sex discrimination, and she identified "a case involving a woman's choice for birth rather than the termination of her pregnancy." "The

34. Ginsburg, Advocating, supra note 22. The authors have not been able to determine why Griswold feared a Supreme Court decision on the merits in Struck. They strongly suspect, however, that he perceived governmental coercion of abortion as an inadvisable context in which to vindicate the federal government's asserted interests in the area of pregnancy discrimination. The context of Struck was very much one of coercion. See, e.g., Janice Goodman, Rhonda Copelon Schoenbrod \& Nancy Stearns, Doe and Roe, Where Do We Go from Here?, 1 WOMEN's RTS. L. REP. 20, 35 (1974) (discussing Struck as a case arising "[i]n the area of coercion").

35. Memorandum Suggesting Mootness, Struck v. Sec'y of Def., 409 U.S. 1071 (1972) (No. 72-178). For Ginsburg's response to the motion, see Opposition to Memorandum for the Respondents Suggesting Mootness, Struck, 409 U.S. 1071 (No. 72-178).

36. Struck, 409 U.S. at 1071.

37. Reva B. Siegel, Comments, in What Roe v. Wade Should Have SaId: The NATION's TOP LEGAL EXPERTS REWRITE AMERICA's MOST CONTROVERSIAL OPINION 244, 245 (Jack M. Balkin ed., 2005). For another account of Struck, see Siegel, supra note 14, at 1385 \& n.169.

38. Geduldig v. Aiello, 417 U.S. 484, 496-97 (1974) (holding that the Equal Protection Clause permitted California to exclude from its disability insurance program the risk of disability resulting from normal pregnancy).

39. Ginsburg Hearings, supra note 1, at 205. 
Struck brief," she recalled, "marks the time when I first thought long and hard about this question."

In the brief, Ginsburg argued that government regulation of pregnant women was presumptively unconstitutional when such regulation enforced the sex roles and stereotypes of the separate spheres tradition-the dyadic structuring of sex roles in which men are expected to perform as breadwinners and women are expected to perform as economically dependent caregivers. Ginsburg portrayed the plaintiff's discharge for pregnancy as perpetuating this tradition:

The central question raised in this case is whether the Air Force, consistent with the equal protection principle inherent in the due process clause of the fifth amendment, may call for immediate discharge of pregnant women officers (whether detection of pregnancy occurs at 8 days or 8 months), unless pregnancy terminates soon after detection, while granting sick leave for all other physical conditions occasioning a period of temporary disability. It is petitioner's position that this distinction reflects arbitrary notions of woman's place wholly at odds with contemporary legislative and judicial recognition that individual potential must not be restrained, nor equal opportunity limited, by law-sanctioned stereotypical prejudgments. Captain Struck seeks no favors or special protection. She simply asks to be judged on the basis of her individual capacities and qualifications, and not on the basis of characteristics assumed to typify pregnant women. ${ }^{41}$

As Ginsburg presented it, the government's discrimination against pregnant officers was a paradigmatic case of the sex-role restrictions that subordinated women. Because it viewed pregnant officers through traditional sex stereotypes, the government excluded all pregnant women from employment, rather than tying eligibility to serve to capacity to work. ${ }^{42}$ The very case at bar illustrated that "many women are capable of working effectively during pregnancy and require only a brief period of absence immediately before and after childbirth. ${ }^{43}$ But the government did not make such an individualized determination. Instead, it barred all pregnant women from serving, putatively to protect them. ${ }^{44}$ Regulations that purport to protect

\footnotetext{
40. Id. at 206.

41. Brief for the Petitioner, supra note 2, at 14 (emphasis added).

42. Id. at 20 .

43. Id. at 35 .

44. Id. at 20 .
} 
pregnant women by forcing them to stop working, the Struck brief sharply observed, "have in practice deprived working women of the protection they most need: protection of their right to work to support themselves and, in many cases, their families as well." ${ }^{45}$ Thus, "mandatory pregnancy discharge reinforces societal pressure to relinquish career aspirations for a hearth-centered existence." ${ }^{46}$

The sex role stereotyping that the Air Force regulation enforced was perhaps most visible in its sex-differentiated approach to parenting. The regulation had defined the terms of service in such a way as to force a choice between employment and parenthood-for women only. ${ }^{47}$ Fathers were allowed to serve in the Air Force while mothers were not: Although "men in the Air Force are not constrained to avoid the pleasures and responsibilities of procreation and parenthood," ${ }^{48}$ Captain Struck "was presumed unfit for service under a regulation that declares, without regard to fact, that she fits into the stereotyped vision... of the 'correct' female response to pregnancy." ${ }^{49}$

The pregnancy regulation challenged in Struck assessed pregnant women's employment qualifications as a group rather than as individuals, and it prohibited the employment of officers who became mothers, while allowing the employment of officers who became fathers. The regulation's prescriptive assumptions about pregnant women reflected and reinforced the sex roles of the separate spheres tradition, ${ }^{50}$ defining women's family role in such a way as to make

45. Id. at 36. Ginsburg also observed that mandatory discharge puts a pregnant woman at a competitive disadvantage with men, "for it deprives her of opportunity for training and work experience during pregnancy and, in many cases, for a prolonged period thereafter." Id.

46. Id. at 37; see also id. ("Loss of her job and accumulated benefits profoundly affect the choices open to her. No position awaits her after childbirth and she is apt to encounter discrimination in locating new employment, this time because she is a mother. If she defers return to the labor force for an extended period, her skills will have grown rusty and, upon attempted re-entry, she will face a further barrier: this time her age as well as her sex and limited work experience will count against her." (footnote omitted)).

47. Id. at 55 .

48. Id. at 48 .

49. Id. at 50-51 (citation and internal quotation marks omitted); see also id. at 52 ("The discriminatory treatment required by the challenged regulation ... reflects the discredited notion that a woman who becomes pregnant is not fit for duty, but should be confined at home to await childbirth and thereafter devote herself to child care." (footnote omitted)).

50. See supra text accompanying note $49 ; c f$. Brief for Petitioner, supra note 2, at 50-51 ("[T]he regulation arbitrarily establishes a presumption of unfitness, distinguishing irrationally between pregnancy and far more debilitating physical conditions that do not occasion automatic 
women dependents and second-class participants in core activities associated with citizenship. "[P]resumably well-meaning exaltation of woman's unique role in bearing children has, in effect, denied women equal opportunity to develop their individual talents and capacities and has impelled them to accept a dependent, subordinate status in society." ${ }_{11}$ Increasingly, Americans were recognizing that laws imposing this traditional role on women violate women's right to the equal protection of the laws. "In very recent years," Ginsburg explained, "a new appreciation of women's place has been generated in the United States. Activated by feminists of both sexes, legislatures and courts have begun to recognize and respond to the subordinate position of women in our society and the second-class status our institutions historically have imposed upon them.",53

Although focusing most heavily on the equal protection argument, Ginsburg lodged two additional constitutional objections to the Air Force regulation. First, she urged that the regulation violated Captain Struck's right to privacy. ${ }^{54}$ Relying on Griswold v. Connecticut ${ }^{55}$ and Eisenstadt $v$. Baird ${ }^{56}$ she argued that the regulation "substantially infringes upon her right to sexual privacy, and her autonomy in deciding "whether to bear ... a child." ${ }^{57}$ In response to the Air Force's suggestion that it was aiming to encourage reproduction control, Ginsburg noted that the Air Force provided additional benefits to service members who become fathers in order

discharge, and differentiating capriciously between a female and male who surrenders a child for adoption.").

51. Id. at 38; see also id. at 38-45 (discussing, inter alia, Hoyt v. Florida, 368 U.S. 57 (1961); Goesaert v. Cleary, 335 U.S. 464 (1948); Muller v. Oregon, 208 U.S. 412 (1908); and Bradwell v. Illinois, 83 U.S. (16 Wall.) 130 (1873)). A similar sentence appears in her brief in Frontiero. See Brief of ACLU as Amicus Curiae at 34-35, Frontiero v. Richardson, 411 U.S. 677 (1973) (No. 71-1694) ("[P]resumably well-meaning exaltation of woman's unique role as wife and mother has, in effect, denied women equal opportunity to develop their individual talents and capacities and has impelled them to accept a dependent, subordinate status in society."). Ginsburg "[w]orked on Frontiero and Struck simultaneously." Letter from Ruth Bader Ginsburg, Assoc. Justice, Supreme Court of the U.S., to Neil S. Siegel (Mar. 31, 2009) (on file with authors).

52. Brief for the Petitioner, supra note 2, at 30-32.

53. Id. at 26-27 (footnote omitted).

54. Id. at 52 ("Imposition of this outmoded standard upon petitioner unconstitutionally encroaches upon her right to privacy in the conduct of her personal life.").

55. Griswold v. Connecticut, 381 U.S. 479 (1965).

56. Eisenstadt v. Baird, 405 U.S. 438 (1972).

57. Brief for the Petitioner, supra note 2, at 54 (quoting Baird, 405 U.S. at 453). 
to encourage them to continue serving. ${ }^{58}$ "The woman," by stark contrast, "serves subject to 'regulation'; her pursuit of an Air Force career requires that she decide not to bear a child." 59

Ginsburg also asserted a free exercise claim, "stress[ing] that the challenged regulation operates with particularly brutal force against women of [Captain Struck's Roman Catholic] faith." ${ }^{, 0}$ This was because "[t]ermination of pregnancy prior to the birth of a living child was not an option [she] could choose." ${ }^{, 11}$ In sum, "the regulation pitted her Air Force career against . . . her religious conscience."

\section{THE LIGHT SHED BY STRUCK}

What does Ruth Bader Ginsburg's merits brief in Struck suggest about her understanding of constitutional equality? Her clear-sighted insistence in the brief that "disadvantageous treatment because of pregnancy is indeed sex discrimination" ${ }^{63}$ indicates that, from the beginning, she had recognized that regulation of pregnancy could be discriminatory. She views some, but not all, regulation of pregnancy as discriminatory, just as she opposes most, but not all, forms of gender differentiation by the government as a violation of equal protection. Ginsburg neither mechanically rejects the potential relevance of differences between the sexes nor invariably embraces them. She is deeply concerned with disadvantageous disparate treatment, yet she contests the government's efforts to impose sex-

58. Id. at 55 (" $[\mathrm{P}]$ arenthood among servicemen is not deterred, indeed additional benefits are provided to encourage men who become fathers to remain in service.").

59. Id.

60. Id. at 56 .

61. Id.

62. Id. (footnote omitted). In the final section of the brief, Ginsburg demonstrated myriad problems with the government's proffered rationales for the regulation: administrative convenience, contraception encouragement, hazards of the combat zone, and readiness and effectiveness of the fighting force. For example, she argued that administrative convenience was rejected in Reed as flatly insufficient to exclude women from opportunities, and that servicemen were in no way encouraged to use contraceptives. Brief for the Petitioner, supra note 2, at 6265. She further noted that pregnancy triggered termination regardless of whether it occurred in a combat zone, and she suggested that the regulation would increase the potential hazards of the combat zone by making it less likely that women would quickly reveal pregnancies within a combat zone. Id. at 65-66 (citing Robinson v. Rand, 340 F. Supp. 37, 40 (D. Colo. 1972)). Finally, she noted that substantially more serious and lasting disabilities, such as drug addiction and alcoholism, did not trigger automatic discharge regardless of where they occurred. See id. at 66-69. The rationale left standing was "blatant prejudice against women for a condition peculiar to their sex." Id. at 69.

63. Ginsburg Hearings, supra note 1, at 206. 
role restrictions primarily because she apprehends the harms that a particular, historically entrenched system of social roles has inflicted on both sexes-especially women. At bottom, the Struck brief suggests, Ginsburg contests legally enforced sex-role differentiation because she views the prevailing system of sex-role differentiation as perpetuating the subordinate status of women. ${ }^{64}$ Heading the list of arbitrary barriers that have plagued women seeking equal opportunity," she thus insisted, "is disadvantaged treatment based on their unique childbearing function." ${ }^{65}$ The harm is not simply the restriction imposed on one woman's opportunities, but the "disadvantaged treatment" regularly inflicted on women because of their childbearing capacity. Ginsburg was concerned with a practice harming a group.

In Struck, Ginsburg highlighted the forms of group disadvantage that discrimination can impose, and she repeatedly related concerns about stereotyping and subordination. For example, Ginsburg emphasized that laws enforcing traditional sex stereotypes inflict harm because they reinforce "the subordinate position of women in our society and the second-class status our institutions historically have imposed upon them." ${ }^{66}$ The Struck brief challenged the government's discriminatory discharge primarily because the government was enforcing sex roles that reinforced the inferior social status of a historically marginalized group. ${ }^{67}$ This antisubordination perspective would shape Ginsburg's approach to equal protection on

64. A wide range of scholars have discussed the antisubordination understanding of equal protection. See Catherine A. MacKinnon, Difference and Dominance: On Sex Discrimination, in FEMINISM UNMODIFIED: Discourses ON LIFE AND LAw 32, 38 (1987); Owen M. Fiss, Groups and the Equal Protection Clause, 5 PHIL. \& PUB. AFF. 107, 151 (1976); Athena D. Mutua, The Rise, Development and Future Directions of Critical Race Theory and Related Scholarship, 84 DENV. U. L. REV. 329, 336 (2006) ("Critical Race Theory's... stance is one of 'antisubordination.”'); Reva B. Siegel, Equality Talk: Antisubordination and Anticlassification Values in Constitutional Struggles over Brown, 117 HARV. L. REV. 1470, 1472-76 (2004); see also Jack M. Balkin \& Reva B. Siegel, The American Civil Rights Tradition: Anticlassification or Antisubordination?, 58 U. MIAMI L. REV. 9, 10 (2003) (arguing "that the scope of the [antisubordination and aniticlassification] principles overlap, [and] that their application shifts over time in response to social contestation and social struggle"); Jill Elaine Hasday, The Principle and Practice of Women's "Full Citizenship": A Case Study of Sex-Segregated Public Education, 101 MICH. L. REV. 755, 769-79 (2002) (discussing different accounts of the antisubordination principle).

65. Brief for the Petitioner, supra note 2, at 34.

66. Id. at 27; see also text accompanying notes 13,51 .

67. See Siegel, supra note 64, at 1472-73 (defining "the antisubordination principle" as "the conviction that it is wrong for the state to engage in practices that enforce the inferior social status of historically oppressed groups"). 
the Court as well. For example, in her majority opinion in United States v. Virginia, she would distinguish sharply between efforts to exclude women from institutions or opportunities in American society, and efforts to include them by taking relevant differences (such as pregnancy) into account. ${ }^{68}$

More specifically, the Struck brief exemplifies that antisubordination values (1) define Ginsburg's understanding of what constitutional equality is, and thus guide her determination of when and how equality values are implicated; (2) identify the perspective from which this equality determination should be made; and (3) connect her constitutional commitments to both equality and liberty. This Part considers each dimension of her thinking in turn.

First, Ginsburg does not regard an antisubordination approach as an alternative to equality analysis. Rather, she regards antisubordination as equality - that is, as equal standing and respect. She insists that sex discrimination exists even when a regulation is purportedly based on physical differences between the sexes, or "when its impact concentrates on a portion of the protected class, for example, married women, mothers, or pregnant women." ${ }^{, 9}$ She so

68. $V M I$ offers the governing statement of the intermediate scrutiny standard and explains the intermediate scrutiny framework as vindicating antisubordination values. Writing for the Court, Justice Ginsburg explains that “'[i]nherent differences' between men and women, we have come to appreciate, remain cause for celebration, but not for denigration of the members of either sex or for artificial constraints on an individual's opportunity." United States v. Virginia (VMI), 518 U.S. 515, 533 (1996). "Sex classifications," she instructs, "may be used to compensate women "for particular economic disabilities [they have] suffered," id. (quoting Califano v. Webster, 430 U.S. 313, 320 (1977) (per curiam)), "to 'promot[e] equal employment opportunity," 'id. (quoting Cal. Fed. Sav. \& Loan Ass'n v. Guerra, 479 U.S. 272, 289 (1987)), and "to advance full development of the talent and capacities of our Nation's people," $i d$. at 533-34. But, she underscores, "such classifications may not be used, as they once were, to create or perpetuate the legal, social, and economic inferiority of women." Id. at 534 (citing Goesaert v. Cleary, 335 U.S. 464, 467 (1948)). Justice Ginsburg brings this same antisubordination analytic to racial equality cases. Cf. Gratz v. Bollinger, 539 U.S. 244, 301 (2003) (Ginsburg, J., dissenting) ("The Constitution instructs all who act for the government that they may not 'deny to any person ... the equal protection of the laws.' In implementing this equality instruction, as I see it, government decisionmakers may properly distinguish between policies of exclusion and inclusion. Actions designed to burden groups long denied full citizenship stature are not sensibly ranked with measures taken to hasten the day when entrenched discrimination and its aftereffects have been extirpated." (citations omitted)).

The same antisubordination perspective guided Ginsburg's argument in Struck, even when she was seeking for her client the same treatment as nonpregnant service members who were temporarily disabled or about to become a parent. The animating concern Ginsburg expressed in Struck and subsequently on the bench was a concern with securing equal status, and not a formalist concern with same treatment.

69. Brief for the Petitioner, supra note 2, at 15. 
insists because her perspective deems constitutionally pertinent not only the existence of a formal sex classification or intentional discrimination but also the effects and social meanings of government regulation of women. These concerns define an antisubordination understanding of equality ${ }^{70}$ which guides determination of when and how equality values are implicated. As illustrated by Struck, such guidance is critical in sex discrimination cases to negotiate when differentiation implicates equality. In contrast to pregnancy discrimination, Ginsburg likely did not devote her litigation efforts to opposing, for example, sex-segregated bathrooms because they do not implicate basic questions about the equal citizenship stature of women. ${ }^{71}$

Second, Ginsburg's Struck brief makes plain that she determines whether equality values are implicated primarily from the standpoint of members of historically excluded groups, and not principally from the perspective of members of included groups-which was the approach taken by, among others, the majority in Plessy v. Ferguson ${ }^{72}$ and Bradwell v. Illinois. ${ }^{73}$ According to the district court in Struck,

70. For a classic focus on the purposes, effects, and social meanings of a practice as determinative under equal protection analysis, see Charles L. Black, Jr., The Lawfulness of the Segregation Decisions, 69 YALE L.J. 421 (1960). Professor Black wrote: "Can a system which, in all that can be measured, has practiced the grossest inequality, actually have been 'equal' in intent, in total social meaning and impact? 'Thy speech maketh thee manifest ...'; segregation, in all visible things, speaks only haltingly any dialect but that of inequality." $I d$. at 426.

71. See, e.g., Ruth Bader Ginsburg, The Fear of the Equal Rights Amendment, WAsH. PosT, Apr. 7, 1975, at A21 ("Separate places to disrobe, sleep, perform personal bodily functions are permitted, in some situations required, by regard for individual privacy."); $c f$. $V M I, 518$ U.S. at $550 \mathrm{n} .19$ ("Admitting women to VMI would undoubtedly require alterations necessary to afford members of each sex privacy from the other sex in living arrangements, and to adjust aspects of the physical training programs. Experience shows such adjustments are manageable." (citations omitted)).

72. Compare Plessy v. Ferguson, 163 U.S. 537, 551 (1896) ("We consider the underlying fallacy of the plaintiff's argument to consist in the assumption that the enforced separation of the two races stamps the colored race with a badge of inferiority. If this be so, it is not by reason of anything found in the act, but solely because the colored race chooses to put that construction upon it."), with Barack Obama, A More Perfect Union, Address at the National Constitution Center (Mar. 18, 2008), available at http://my.barackobama.com/page/content/hisownwords ("[T]he path to a more perfect union means acknowledging that what ails the African-American community does not just exist in the minds of black people; that the legacy of discriminationand current incidents of discrimination, while less overt than in the past-are real and must be addressed.").

73. Bradwell v. Illinois, 83 U.S. (16 Wall.) 130 (1872). The Court upheld the exclusion of women from the practice of law. $I d$. at 139. In a concurring opinion, Justice Bradley wrote that "[t]he paramount destiny and mission of woman are to fulfil the noble and benign offices of wife and mother. This is the law of the Creator." Id. at 141 (Bradley, J., concurring). "Although the method of communication between the Creator and the jurist is never disclosed," Ginsburg 
"[s]omebody said that [women are a little more difficult when they are pregnant than when they are not], that there is some change in their personality, and their capabilities. It could well be that the Air Force felt that when they formulated their policy and rules ...." ${ }^{, 74}$ By stark contrast, Ginsburg noted the many female doctors and nurses in obstetrics and other medical fields who work right up to the day of delivery, ${ }^{75}$ and she continually framed the case for the Court from Captain Struck's point of view. To reiterate, she drew from the "petitioner's experience" to substantiate her assertion that "many women are capable of working effectively during pregnancy and require only a brief period of absence immediately before and after childbirth. ${ }^{.76}$ She underscored the devastating impact of the Air Force regulation on the career prospects of a military woman and the lack of any justification for the regulation that did not sound most plausibly in traditional stereotypes about how women are "supposed" to respond to a pregnancy. ${ }^{77}$

wrote in her Struck brief, “divine ordinance' has been a dominant theme in decisions justifying laws establishing sex-based classifications." Brief for the Petitioner, supra note 2, at 39.

74. Brief for the Petitioner, supra note 2, at $35 \mathrm{n} .29$ (alteration in original) (quoting Transcript of Oral Argument at 23, Struck v. Sec'y of Defense, 460 F.2d 1372 (1971) (No. 711150) (statement of William N. Goodwin, J.)).

75. Id. at 35 \& n.29.

76. Id. at 35 .

77. Similarly, Justice Ginsburg viewed a recent sex discrimination case from the perspective of the victim:

The Court's insistence on immediate contest overlooks common characteristics of pay discrimination. Pay disparities often occur, as they did in Ledbetter's case, in small increments; cause to suspect that discrimination is at work develops only over time. Comparative pay information, moreover, is often hidden from the employee's view. Employers may keep under wraps the pay differentials maintained among supervisors, no less the reasons for those differentials. Small initial discrepancies may not be seen as meet for a federal case, particularly when the employee, trying to succeed in a nontraditional environment, is averse to making waves.

Pay disparities are thus significantly different from adverse actions "such as termination, failure to promote... or refusal to hire," all involving fully communicated discrete acts, "easy to identify" as discriminatory. It is only when the disparity becomes apparent and sizable, e.g., through future raises calculated as a percentage of current salaries, that an employee in Ledbetter's situation is likely to comprehend her plight and, therefore, to complain. Her initial readiness to give her employer the benefit of the doubt should not preclude her from later challenging the then current and continuing payment of a wage depressed on account of her sex.

Ledbetter v. Goodyear Tire \& Rubber Co., 127 S. Ct. 2162, 2178-79 (2007) (Ginsburg, J., dissenting) (citation omitted). Congress subsequently endorsed the perspective that Ginsburg adopted in dissent. The Lilly Ledbetter Fair Pay Act of 2009 was the first bill that President Obama signed into law. See Sheryl Gay Stolberg, Obama Signs Equal-Pay Legislation, N.Y. TiMES, Jan. 30, 2009, http://www.nytimes.com/2009/01/30/us/politics/30ledbetter-web.html. 
Third, although Ginsburg stressed the equality dimension of discharge-for-pregnancy regulations in her Struck brief, ${ }^{78}$ she also asserted a substantive due process claim and advanced it in a way that reveals the link between her views on constitutional equality and constitutional liberty. ${ }^{79}$ (At the time of Roe, feminists understood Struck as both an equality and a liberty case-just as they understood $R o e .{ }^{80}$ ) In making the due process argument, Ginsburg continued to speak in part in terms of "discrimination" and social subordination. ${ }^{81}$ This is not because she was conceptually confused, but because she registered that laws intervening in major life decisions and enforcing status roles may simultaneously implicate both equality and libertyequal protection and due process. Restricting women's liberty may be a means to the end of communicating inequality, and discriminating against women may diminish their opportunities to fashion fulfilling lives. ${ }^{82}$ For Ginsburg, it seems less important to disentangle these two clusters of constitutional commitments than it is to emphasize the ways in which they are intertwined. ${ }^{83}$

78. See Ginsburg Hearings, supra note 1, at 206 ("The main emphasis was on her equality as a woman, vis-a-vis a man who was equally responsible for the conception ...."); id. ("I did think about it, first and foremost, as differential treatment of the woman, based on her sex.").

79. See id. at 205 ("[I]t has never in my mind been an either/or choice, never one rather than the other; it has been both."); id. at 206 ("At no time did I regard it as an either/or, one pocket or the other issue.").

80. See Goodman et al., supra note 34, at 35 (discussing reproductive freedom as the right to decide whether to have or not to have children without state interference, and describing Struck as a case about "coercion"). For an account of the feminist reproductive rights claims of the era, see, for example, Reva B. Siegel, Sex Equality Arguments for Reproductive Rights: Their Critical Basis and Evolving Constitutional Expression, 56 EMORY L.J. 815 (2007). "In these early briefs, liberty talk and equality talk were entangled as emanations of different constitutional clauses." Id. at 823 .

81. See, e.g., Brief for the Petitioner, supra note 2, at 52 ("The discriminatory treatment required by the challenged regulation ... reflects the discredited notion that a woman who becomes pregnant is not fit for duty, but should be confined at home to await childbirth and thereafter devote herself to child care. Imposition of this outmoded standard upon petitioner unconstitutionally encroaches upon her right to privacy in the conduct of her personal life." (footnote omitted)).

82. See Reva B. Siegel, Dignity and the Politics of Protection: Abortion Restrictions Under Casey/Carhart, 117 YALE L.J. 1694, 1738-45, 1763-66 (2008) (developing this insight); id. at 1744-45 ("Concern that restrictions on women's liberty can communicate meanings about women's social standing lies at the heart of the sex discrimination cases, especially those cases invalidating laws that deny women autonomy to make decisions about their family roles.").

83. Justice Ginsburg has recently reemphasized the close link between constitutional equality and constitutional liberty in the area of reproductive rights. See, e.g., Gonzales v. Carhart, 127 S. Ct. 1610, 1641 (2007) (Ginsburg, J., dissenting)). Her opinion in Gonzales v. Carhart cites equal protection sex discrimination cases as support for the abortion right. See id. at 1649. 
Some feminists, however, have criticized Justice Ginsburg for advocating a sex-blind formal equality in sex discrimination cases; they depict her as only and overly concerned with arbitrary sex-based differentiation $^{84}$-in substantial part because she championed the causes of male plaintiffs in certain such cases ${ }^{85}$ Much of this criticism occurred in an era of backlash, when an increasingly conservative Court was employing a formalist conception of classification to make equal protection law blind to problems of disparate impact and hostile to affirmative action, in sex as well as race cases. ${ }^{86}$ In such an

84. See, e.g., Baer, supra note 17, at 216, 231 ("Fourteen of the [nineteen] cases decided since Craig were brought by men. Lower court cases exhibit a similar pattern. The women's won-lost record is better than the men's; moreover, victories by men do not necessarily harm women and may benefit them. But so far men have been the primary beneficiaries of the new sexual equality doctrine. Ruth Bader Ginsburg has given no indication that this outcome troubles her. She continues to regard sex equality not as requiring the elimination of male supremacy, but as a problem of discrimination, of basing decisions on a person's sex." (footnote omitted)); David Cole, Strategies of Difference: Litigating for Women's Rights in a Man's World, 2 L. \& INEQUALITY 33, 55 (1984) ("Ginsburg chose to litigate issues that she could frame as hurting both men and women, rather than issues, like pregnancy discrimination, where the harm fell on women alone. She sought to deny women's 'difference;' this strategy both limited her range and increased her chances for success. Ginsburg's classic argument was to insist that women were like men. She sought to show that women were similarly situated, but that society had treated them differently because of stereotypical 'old notions' and 'archaic assumptions' about sex roles. .. . Nevertheless, Ginsburg's assimilationist method could not address the entire range of women's rights issues. Assimilation is most obviously an insufficient response to issues of reproductive freedom. In this area, women are biologically different, and therefore women must be treated differently to be treated equally."). Ginsburg has herself summarized much of the criticism. See Ruth Bader Ginsburg \& Barbara Flagg, Some Reflections on the Feminist Legal Thought of the 1970s, 1989 U. CHI. LEGAL F. 9, 17 ("[Feminist legal scholars] have portrayed the 1970 s litigation as assimilationist in outlook, insistent on formal equality, opening doors only to comfortably situated women willing to accept men's rules and be treated like men, even a misguided effort that harmed more women than it helped.").

85. See, e.g., Craig v. Boren, 429 U.S. 190 (1976) (declaring unconstitutional an Oklahoma law that allowed women to buy 3.2 percent beer at age eighteen but did not allow men to buy such beer until age twenty-one); Weinberger v. Wiesenfeld, 420 U.S. 636 (1975) (declaring unconstitutional a provision of the Social Security Act that allowed a woman whose husband died to receive benefits based on his earnings but did not allow a man whose wife died to receive benefits based on her earnings); Moritz v. Comm'r of Internal Revenue, 469 F.2d 466 (10th Cir. 1972) (declaring unconstitutional a provision of the Internal Revenue Code that denied a deduction for dependent-care expenses to a man who never married while granting the deduction to women, widowers, divorcés, and husbands in certain circumstances). Wiesenfeld in particular was "[a] case near and dear to my heart." Ruth Bader Ginsburg, quoted in AMY LEIGH CAMPBELL, RAISING THE BAR: RUTH BADER GINSBURG AND THE ACLU WOMEN'S Rights PROJECT 93 (2004). This is perhaps because a man was ready, willing, and able to raise his child in a society that deemed him perverse for wanting to do what had long been deemed "women's work."

86. For an account of these developments in race discrimination law, see generally Fiss, supra note 64; Siegel, supra note 64, at 1535-38. One of the authors has explored the 
era, it was possible to (mis)construe Ginsburg's selection of male sex discrimination plaintiffs as of a piece with the formalist reasoning of the Burger Court.

As the Struck brief shows, however, it was not. Ginsburg's selection of a pregnant plaintiff to advance the equal protection claims of women demonstrates that she was no formalist. In Struck itself, Ginsburg explained that she was challenging laws that enforce traditional sex-role stereotypes because such laws lead to the subordination of women: "presumably well-meaning exaltation of woman's unique role in bearing children has, in effect, denied women equal opportunity to develop their individual talents and capacities and has impelled them to accept a dependent, subordinate status in society." Captain Struck "was presumed unfit for service under a regulation that declares, without regard to fact, that she fits into the stereotyped vision... of the 'correct' female response to pregnancy." ${ }^{\prime 88}$ Ginsburg's message was clear: sex-role stereotypes of the separate spheres tradition subordinate women by denying them an equal chance to make their own meaning of their lives.

In an important forthcoming article, Cary Franklin has reconstructed the social theory on which Ginsburg's early litigation strategy was premised. ${ }^{89}$ As Franklin shows, Ginsburg understood that the stereotypes contested by the male plaintiffs she represented were part of a dyadic system of gender roles that defined men as breadwinners and women as dependent caregivers in ways that subordinated women. ${ }^{90}$ Ginsburg's antistereotyping approach was not

implications in sex discrimination law. See Reva B. Siegel, "The Rule of Love": Wife Beating as Prerogative and Privacy, 105 YALE L.J. 2117, 2188-95 (1996) (showing how the Court's rejection of disparate impact claims in Washington v. Davis, 426 U.S. 229 (1976), and Personnel Administrator v. Feeney, 442 U.S. 256 (1979), shielded from equal protection scrutiny "facially neutral" practices (such as domestic violence policies) that have long played a role in subordinating women).

87. Brief for the Petitioner, supra note 2, at 38; see also id. at 38-45 (discussing, inter alia, Hoyt v. Florida, 368 U.S. 57 (1961); Goesaert v. Cleary, 335 U.S. 464 (1948); Muller v. Oregon, 208 U.S. 412 (1908); and Bradwell v. Illinois, 83 U.S. (16 Wall.) 130 (1873)).

88. Id. at 50-51 (citation and internal quotation marks omitted).

89. Cary Franklin, The Anti-Stereotyping Principle in Constitutional Sex Discrimination Law, 85 N.Y.U. L. REV. (forthcoming April 2010) (manuscript on file with the Duke Law Journal).

90. See id. at 3-4. Franklin explains that "Ginsburg derived the anti-stereotyping principle in part from ... the law and politics of Sweden, which began in the early 1960s to wage an ambitious, decades-long campaign against sex-role enforcement." Id. at 4. Specifically, the Swedish anti-stereotyping ideals that would powerfully impact Professor Ginsburg went far beyond insisting on formal equality between the sexes. "Proponents of jämställdhet," as this 
simply hostile to sex classification or sex differentiation; she opposed traditional sex stereotypes insofar as they were part of a system of social roles and understandings that anchored women's inequality.

Ginsburg's effort to defend a pregnant member of the Air Force is of a piece with her interest in bringing cases on behalf of caregiving men. Neither reflects a formal view of equality. Instead, Ginsburg challenged laws enforcing traditional sex stereotypes because she understood them as part of a larger set of social arrangements that ultimately subordinated women.

Ginsburg's articulation of an antisubordination perspective in Struck is even more remarkable when the brief is situated in historical context. Today, antisubordination arguments tend to be associated with Owen Fiss's 1976 expression of antisubordination themes in Groups and the Equal Protection Clause ${ }^{91}$ and Catherine MacKinnon's 1979 use of an antisubordination analytic in Sexual Harassment of Working Women. ${ }^{92}$ The Struck brief evidences Ginsburg speaking in an antisubordination register in 1972, carrying into the sex equality context concerns about status inequality expressed in debates over Brown v. Board of Education. ${ }^{93}$ One cannot help but be struck (so to speak) by the timing of this brief. Although Ginsburg was by no means the only legal feminist at the time to conceive sex equality from an antisubordination perspective, she did play an early and leading role in showing how concerns about social

Swedish theory of gender equality was known, "believed sex classifications were often necessary in order to break down traditional conceptions of men and women's roles; their aim was not to eliminate formal sex classifications but to liberate both sexes from prescriptive sex stereotypes." $I d$. at 17. According to Franklin, it was for this reason, and not because of strategic considerations or a commitment to formal equality, that Professor Ginsburg sought out male plaintiffs in several of the cases that she litigated. For citations to some of these cases, see supra note 85 .

91. Fiss, supra note 64 , at 157 (proposing to substitute for the equal treatment principle a group-disadvantaging principle premised on a theory of "status-harm" that would inquire whether a challenged practice would "impair or threaten or aggravate the status or position of the group").

92. CATHERine A. MacKinnon, SeXual Harassment of Working Women: A CASE OF SEX DISCRIMINATION 117 (1979) (proposing that courts determining whether a practice discriminates on the basis of sex inquire "whether the policy or practice in question integrally contributes to the maintenance of an underclass or deprived position because of gender status"); see also supra note 64 (citing scholarship on antisubordination).

93. Brown v. Bd. of Educ., 347 U.S. 483 (1954). For discussions of debates about the meaning of Brown, see Christopher W. Schmidt, Brown and the Colorblind Constitution, 94 Cornell L. REV. 203, 231-37 (2008); Neil S. Siegel, Race-Conscious Student Assignment Plans: Balkanization, Integration, and Individualized Consideration, 56 DUKE L.J. 781, 830-33, 841-43 (2006); Siegel, supra note 64, at 1532-44. 
subordination illuminate the problem of sex discrimination. Her prescience has not been sufficiently recognized.

The timing of Ginsburg's Struck brief is noteworthy for another reason. Ginsburg persuasively urged the Court to view pregnancy discrimination as a form of sex discrimination, and sex discrimination as inextricably intertwined with women's autonomy to decide whether to bear children, at a time when the entire landscape of modern sex discrimination law and substantive due process law had yet to be worked out. Ginsburg and the women's movement talked about pregnancy discrimination in a way that ties together pregnancy discrimination and women's equality, and women's equality and reproductive freedom, ${ }^{94}$ before the Court split them apart in cases such as Roe v. Wade, Frontiero v. Richardson, and Geduldig v. Aiello. The Court made some fateful choices in those cases: to focus its sex equality jurisprudence on cases other than pregnancy, and so to develop its sex equality jurisprudence in isolation from its abortion jurisprudence. ${ }^{95}$ It is only by apprehending where the law was and where it was about to go when Struck was litigated that one can fully appreciate the momentousness, the audacity, and the profundity of this brief-as well as the implications of its erasure. In 1976, the Court embraced the intermediate scrutiny standard for sex discrimination claims in a case involving men who sought to purchase 3.2 percent beer. ${ }^{96}$ How would our understanding of sex discrimination and substantive due process law differ had the Court recognized the equal protection claim of a pregnant service woman who challenged the government's requirement that she have an abortion or lose her position in the military?

\section{BACK TO THE FUTURE}

This Essay has not come close to recovering all of the virtues of Ruth Bader Ginsburg's merits brief in Struck v. Secretary of Defense. Nor has it identified all of the interesting questions and ironies that it

94. See Linda Greenhouse \& Reva Siegel, On the RoAd to RoE V. WAdE: How Americans TAlKed About Abortion in the Years Before the Supreme Court's LANDMARK RULING (forthcoming 2010) (reproducing feminist arguments for abortion rights from 1969-73 that invoke both privacy and equality and analyze the regulation of abortion as part of the regulation of motherhood).

95. For a discussion of these two points, see infra Part IV.

96. See Craig v. Boren, 429 U.S. 190, 197 (1976). 
implicates. ${ }^{97}$ The brief is a veritable treasure trove of accurate predictions, subtle insights, and effective advocacy. Among other things, it mentions the possibility of intermediate scrutiny for sex classifications ${ }^{98}$ leaves the door open for "compensatory treatment" of women "in special situations," adopted Ginsburg's position, ${ }^{100}$ gently gestures in the direction of the link between sex discrimination and burdensome regulations of abortion, ${ }^{101}$ and emphasizes themes of sexual intimacy and privacy, ${ }^{102}$ which decades later would find expression in the Court's dawning recognition of the equal citizenship stature of homosexuals. ${ }^{103}$ Throughout the brief, Ginsburg's distinct and powerful voice is present. For legal academics who care about the development of Justice Ginsburg's views on sex discrimination, the brief is essential reading.

Most significantly, however, the brief deserves a wide readership because of what it instructs about the present. It may soon be time to reimagine what is possible in this corner of constitutional law. In 1972, Professor Ginsburg made a compelling argument that pregnancy discrimination is sex discrimination because of the social understandings about women it reflects and the profound limitations on their lives it enforces. Although the Court eventually accepted

97. Particularly in light of how cultural battle lines have been drawn in the twenty-first century, it is illuminating to see Justice Ginsburg's voice deployed in the service of both the equal citizenship stature of women and one particular woman's religiously based opposition to procuring an abortion. From the vantage point of the present, it may be ironic that Ginsburg's views on sex discrimination and abortion first developed in this setting. But it serves as an instructive reminder that Americans today agree about more than they often realize.

98. Brief for the Petitioner, supra note 2, at 26 ("In addition to the two commonly differentiated review standards, some of the decisions of this Court suggest an intermediate standard.").

99. Id. at $29 \mathrm{n} .24$ ("It is not urged here that extensive compensatory treatment is needed to redress past discrimination against women. [A Second Circuit decision], however, indicates that in special situations compensatory treatment may be appropriate." (referencing Gruenwald v. Gardner, 390 F.2d 591 (2d Cir. 1968)).

100. See, e.g., id. at 46 ("In 1971, two legal scholars-both of them male-examined the record of the judiciary in sex discrimination cases; they concluded that the performance of American judges in this area 'can be succinctly described as ranging from poor to abominable."').

101. Brief for the Petitioner, supra note 2, at $54 \mathrm{n} .55$ ("Griswold alone, or in conjunction with Baird, has been cited in numerous lower court decisions holding that women have a right to determine for themselves, free from unwarranted governmental intrusion, whether or not to bear children." (citing Roe v. Wade, 314 F. Supp. 1217 (N.D. Tex. 1970))).

102. See, e.g., supra note 57 and accompanying text.

103. See Lawrence v. Texas, 539 U.S. 558 (2003); Romer v. Evans, 517 U.S. 620 (1996). 
much of her general vision of sex equality, it was slow to recognize discrimination against pregnant women as a paradigmatic form of sex discrimination. In 1974, the Court in Geduldig acknowledged that discrimination against pregnant women might be animated by invidious judgments about women, but found exclusion of pregnancy benefits from otherwise comprehensive disability insurance to be a rational method of saving taxpayer monies. ${ }^{104}$ The Court did, however, yield to the instruction of Congress that discrimination against pregnant women can violate federal employment discrimination law, and began to enforce the Pregnancy Discrimination Amendment (PDA) (1978) to Title VII of the 1964 Civil Rights Act. ${ }^{105}$ After three decades of PDA litigation, Americans are more receptive to the claim that discrimination against pregnant women is sex discrimination, and they have come to view it as a claim of fundamental-even constitutional-magnitude. ${ }^{106}$ With these

104. See Geduldig v. Aiello, 417 U.S. 484, 496 (1974). The Gedulgig decision reasoned:

While it is true that only women can become pregnant it does not follow that every legislative classification concerning pregnancy is a sex-based classification like those considered in [Reed and Frontiero]. Normal pregnancy is an objectively identifiable physical condition with unique characteristics. Absent a showing that distinctions involving pregnancy are mere pretexts designed to effect an invidious discrimination against the members of one sex or the other, lawmakers are constitutionally free to include or exclude pregnancy from the coverage of legislation such as this on any reasonable basis, just as with respect to any other physical condition.

Id. at 496 n.20 (emphasis added). This much quoted passage from Geduldig is often read as denying that pregnancy discrimination is sex discrimination. In fact, the passage in question reasons that pregnancy discrimination is not always sex discriminatory or invidious, but sometimes may be. As shown in this Part, in the years since its decision in Geduldig, the Court has come to recognize that gender bias in the regulation of pregnancy is more prevalent than perhaps it first believed.

105. Robert C. Post \& Reva B. Siegel, Legislative Constitutionalism and Section Five Power: Policentric Interpretation of the Family and Medical Leave Act, 112 YALE L.J. 1943, 2042 n.309 (2003).

106. Consider, for example, the likely political prospects of an attempt to repeal the PDA, which responded to Geduldig and Gilbert. Gilbert followed Geduldig's reasoning and held that a disability benefit plan excluding disabilities related to pregnancy was not sex-based discrimination within the meaning of Title VII of the Civil Rights Act of 1964. Gen. Elec. Co. v. Gilbert, 429 U.S. 125, 136 (1976). For a discussion of the PDA's role in shaping popular and judicial understandings of sex discrimination, see Reva B. Siegel, "You've Come a Long Way, Baby”: Rehnquist's New Approach to Pregnancy Discrimination in Hibbs, 58 STAN. L. REV. 1871, 1897-98 (2006).

The Court recently discussed this case law and Congress's responses to it in $A T \& T$ Corp. v. Hulteen, 129 S. Ct. 1962 (2009). There, the Court held that an employer does not necessarily violate the PDA when it pays pension benefits based in part on an accrual rule, applied only prior to the PDA's enactment, that gave less retirement credit for pregnancy leave than for medical leave generally. $I d$. at 1966. Only Justice Breyer joined Justice Ginsburg's passionate dissent, in which she described Gilbert as wrong-indeed, "astonishing," 
changes, the Court has begun to move closer to Ginsburg's understanding of sex discrimination without wholeheartedly embracing her point of view. ${ }^{107}$

For example, it was Chief Justice Rehnquist-Rehnquist!-who wrote the majority opinion in Nevada Department of Human Resources v. Hibbs. ${ }^{108}$ Hibbs upheld the leave provision of the Family and Medical Leave Act of 1993 (FMLA) ${ }^{109}$ as a valid exercise of Congress's power under Section 5 of the Fourteenth Amendment to combat unconstitutional sex discrimination..$^{110}$ Remarkably, the Hibbs Court expressly registered the sometimes deep divide between formal equality and substantive equality: in an America in which women are still required to serve as the principal caregivers in their families,

"egregious[]," and "aberrational"- the day it was decided. Id. at 1977, 1979 (Ginsburg, J., dissenting). All of the other Justices allowed AT\&T to perpetuate pay differentials in the postPDA period that were attributable to pregnancy discrimination that occurred in the pre-PDA period.

But if seven Justices allowed AT\&T to perpetuate pay differentials attributable to prePDA discrimination, none of them said anything in defense of Geduldig and Gilbert's reasoning. In essence, the majority reasoned that the employer's discrimination was reasonable when it occurred, even if it was no longer an acceptable way to treat women. Ginsburg's characterization of Gilbert provoked no defense of the decision from any other Justice. This is in stark contrast to what commonly occurs when individual Justices speak their minds forcefully in controversial areas of law. (Consider, for instance, Justice Scalia's response to Justice Stevens regarding the constitutionality of the death penalty in Baze v. Rees, 128 S. Ct. 1520 (2008).) Both the narrow holding and the loud silences in Hulteen suggest little enthusiasm on the early Roberts Court for defending the view of the relation between pregnancy discrimination and sex discrimination espoused in Geduldig and Gilbert.

107. For a discussion of these developments from the perspective of legal doctrine, see Neil S. Siegel \& Reva B. Siegel, Pregnancy and Sex Role Stereotyping, from Struck to Carhart, 70 OHIO ST. L.J. (forthcoming November 2009) (symposium essay honoring the jurisprudence of Justice Ruth Bader Ginsburg).

108. Nev. Dep’t of Human Res. v. Hibbs, 538 U.S. 721 (2003). Commentators have noted the magnitude of Chief Justice Rehnquist's shift in position from his early days on the Court to VMI, see United States v. Virginia (VMI), 518 U.S. 515, 558-66 (1996) (Rehnquist, C.J., concurring in the judgment), and then to Hibbs. See, e.g., Linda Greenhouse, Introduction: Learning to Listen to Ruth Bader Ginsburg, N.Y. CITY L. REV. 213, 218-19 (2004); Deborah Jones Merritt \& David M. Lieberman, Ruth Bader Ginsburg's Jurisprudence of Opportunity and Equality, 104 COLUM. L. REV. 39, 47 (2004); Siegel, supra note 106, at 1871-98. The evolution of the late Chief Justice's views on sex discrimination is as striking as the development of his relationship with Justice Ginsburg is endearing. During the year one of the authors spent in her chambers, she often expressed her devotion to him by calling him "the Chief" or "my Chief." See, e.g., Ruth Bader Ginsburg, Constitutional Adjudication in the United States as a Means of Advancing the Equal Stature of Men and Women Under the Law, 26 HOFSTRA L. REV. 263, 26770 (1997) (discussing, inter alia, the change in Chief Justice Rehnquist's views on sex discrimination and referring to him as "my now Chief").

109. 29 U.S.C. $\$ 2612(a)(1)(c)(2006)$.

110. Hibbs, 538 U.S. at 740 . 
mere formal equality in the administration of family leave benefitsfor example, allowing no leave time for any employees-would "exclude far more women than men from the workplace" therefore would not effectively "combat the stereotypes about the roles of male and female employees that Congress sought to eliminate" in passing the FMLA. ${ }^{112}$

Hibbs reflects the understanding that new mothers and pregnant women face intense stereotyping in the workplace. Hibbs observes that "denial or curtailment of women's employment opportunities has [long] been traceable directly to the pervasive presumption that women are mothers first, and workers second." "This prevailing ideology about women's roles," the Court agreed with Congress, has "justified discrimination against women when they are mothers or mothers-to-be." 114 In these and other passages, Hibbs clearly indicates that regulation of pregnant women can amount to constitutionally actionable sex discrimination; for example, the Court suggests that laws giving benefits to pregnant employees that are premised on traditional sex-role stereotypes violate equal protection. ${ }^{115}$ The Hibbs Court had no occasion to reconcile the opinion's reasoning with Geduldig, ${ }^{116}$ but the reasoning in Hibbs parallels Ginsburg's reasoning in Struck, not the Burger Court's reasoning in Geduldig. ${ }^{117}$ Although Geduldig is commonly read as holding that discrimination against pregnant women can never be sex discrimination, after Hibbs it is time to read Geduldig more precisely, as holding that discrimination

111. Id. at 738 .

112. Id. at 734. The implications of such reasoning for the scope of congressional power under Section 5 are broad indeed. See, e.g., Franklin, supra note 89, at 47-50 (persuasively defending the constitutionality of legislation (1) expanding the FMLA's coverage to small and midsize employers and to provide covered employees with paid leave; (2) requiring paid sick leave; (3) providing affordable childcare; and (4) addressing sex segregation in the American labor market).

113. Hibbs, 538 U.S. at 736 (quoting The Parental and Medical Leave Act of 1986: J. Hearing Before the Subcomm. on Labor-Mgmt. Relations and the Subcomm. on Labor Standards of the H. Comm. on Educ. and Labor, 99th Cong., 2d Sess., 100 (1986) (statement of Women's Legal Defense Fund)).

114. Id. (quoting The Parental and Medical Leave Act of 1986, supra note 113, at 100).

115. See id. at 731 \& n.5.

116. For further discussion of Geduldig, see supra note 8 and accompanying text.

117. Geduldig v. Aiello, 417 U.S. 484, 496 n.20 (1974). For a discussion of the Court's reasoning in Hibbs, see generally Siegel, supra note 106, at 1889-91. 
against pregnant woman is not always sex discrimination-but sometimes can be. ${ }^{118}$

In addition to arguing that pregnancy discrimination is sex discrimination, Ginsburg also intimated on behalf of Captain Struck in 1972 that women's equality and women's reproductive freedom are inextricably linked. She noted the many lower courts, including the federal district court in Roe, that had read the Court's contraception decisions as "holding that women have a right to determine for themselves, free from unwarranted governmental intrusion, whether or not to bear children." 119 Although Roe incompletely grasped this link and discussed the abortion right from the perspective of a woman's physician, ${ }^{120}$ Planned Parenthood of Southeastern Pennsylvania $v$. Casey $^{121}$ came closer to registering the true stakes. The plurality opinion in Casey stressed the liberty of the pregnant

118. For further elaboration of this reading of Geduldig, see generally Siegel \& Siegel, supra note 107 . Because the PDA is firmly entrenched, it may be unclear what would be the practical implications in the pregnancy context of recognizing pregnancy discrimination as unconstitutional sex discrimination. There might be some practical consequences in light of potential Eleventh Amendment objections to enforcing the PDA in certain settings. Yet a Court that takes Hibbs seriously would be unlikely to impose any Section 5 impediment to enforcing the PDA against the states. And a Court that does not take Hibbs seriously would be unlikely to recognize pregnancy discrimination as unconstitutional sex discrimination. Regardless, broader doctrinal implications would follow from recognizing that physical differences between the sexes are the beginning, not the end, of the constitutional conversation about women's equality. For example, Cary Franklin suggests that, after VMI and Hibbs, it no longer seems open to the federal government to assert that physical differences between the sexes justify excluding women from selective service registration, eligibility for the draft, and various combat positions. See Franklin, supra note 89, at 51-53. Nor, she argues, does it seem permissible for the government to support programs of single-sex education that reinforce traditional sex-role stereotypes. See id. at 46-47. Nor, she astutely notes, are certain rationales for prohibiting gay marriage reconcilable with an anti-stereotyping conception of constitutional equality. See id. at $57-65$.

119. See Brief for Petitioner, supra note 2, at 54 n.55; see also text accompanying note 101. For subsequent discussions, see generally Ruth Bader Ginsburg, Sex Equality and the Constitution, 52 Tul. L. REV. 451 (1978); Ruth Bader Ginsburg, Some Thoughts on Autonomy and Equality in Relation to Roe v. Wade, 63 N.C. L. REV. 375 (1985).

120. Roe v. Wade, 410 U.S. 113, 163 (1973) ("[F]or the period of pregnancy prior to this 'compelling' point, the attending physician, in consultation with his patient, is free to determine, without regulation by the State, that, in his medical judgment, the patient's pregnancy should be terminated. If that decision is reached, the judgment may be effectuated by an abortion free of interference by the State."); id. at 164 ("For the stage prior to approximately the end of the first trimester, the abortion decision and its effectuation must be left to the medical judgment of the pregnant woman's attending physician.").

121. Planned Parenthood of Se. Pa. v. Casey, 505 U.S. 833 (1992). 
woman, ${ }^{122}$ and a majority of Justices began to articulate the sex equality implications of intrusive restrictions on abortion. ${ }^{123}$ To be sure, the Court in Gonzales v. Carhart $^{124}$ may have taken a step in a very different direction. ${ }^{125}$ But four Justices adopted Justice Ginsburg's apprehension that "legal challenges to undue restrictions on abortion procedures do not seek to vindicate some generalized notion of privacy; rather, they center on a woman's autonomy to determine her life's course, and thus to enjoy equal citizenship stature."126 Moreover, Justice Kennedy's majority opinion makes conceptual sense only if one presupposes the continued existence of the abortion right, ${ }^{127}$ and Kennedy has long recognized the link

122. Id. at 876 (plurality opinion) ("In our view, the undue burden standard is the appropriate means of reconciling the State's interest with the woman's constitutionally protected liberty.").

123. See, e.g., id. at 852 ("Her suffering is too intimate and personal for the State to insist, without more, upon its own vision of the woman's role, however dominant that vision has been in the course of our history and our culture. The destiny of the woman must be shaped to a large extent on her own conception of her spiritual imperatives and her place in society."); id. at 856 ("The ability of women to participate equally in the economic and social life of the Nation has been facilitated by their ability to control their reproductive lives."); id. at 897 (stating that the views expressed in Bradwell and Hoyt "of course, are no longer consistent with our understanding of the family, the individual, or the Constitution").

124. Gonzales v. Carhart, 127 S. Ct. 1610 (2007).

125. See, e.g., Neil S. Siegel, The Virtue of Judicial Statesmanship, 86 TEX. L. REV. 959, 1014-30 (2008).

126. Carhart, 127 S. Ct. at 1641 (Ginsburg, J., joined by Stevens, Souter, and Breyer, JJ., dissenting) (citing Reva Siegel, Reasoning from the Body: A Historical Perspective on Abortion Regulation and Questions of Equal Protection, 44 STAN. L. REV. 261 (1992), and Sylvia Law, Rethinking Sex and the Constitution, 132 U. PA. L. REV. 955, 1002-28 (1984)); see also, e.g., Siegel, supra note 80, at 837-38 (situating Justice Ginsburg's opinion in Carhart in a survey of sex equality arguments for reproductive rights); Cass R. Sunstein, Editorial, Ginsburg's Dissent May Yet Prevail, L.A. Times, Apr. 20, 2007, at A31 (noting that in Carhart, Justice Ginsburg "attempted to re-conceive the foundations of the abortion right, basing it on well-established constitutional principles of equality").

127. Carhart exemplifies the often real but notoriously blurry distinction between constitutional politics and constitutional law. On the one hand, opponents of abortion have used the issue of so-called partial-birth abortion to undermine the abortion right in general, see Siegel, supra note 82, at 1707-09, and the Carhart Court effectively overruled precedent in order to uphold a federal ban on the procedure, see Siegel, supra note 125, at 1020-21. On the other hand, the Court reasoned that the ban could survive a facial challenge because the procedure was sufficiently distinct from abortion in general and did not impose an undue burden on the right to abortion. Carhart, $127 \mathrm{~S}$. Ct. at 1627. For one attempt to understand the ragged relationship between constitutional politics and constitutional law, see generally Robert C. Post \& Neil S. Siegel, Theorizing the Law/Politics Distinction: Neutral Principles, Affirmative Action, and the Enduring Legacy of Paul Mishkin, 95 CAL. L. REV. 1473 (2007). One of the authors has explored this relationship in more depth. See generally Siegel, supra note 125 (conceiving law as an institution that must account for the conditions of its own legitimation); Neil S. Siegel, Umpires at Bat: On Integration and Legitimation, 24 CONST. COMMENT. 701 (2007) (identifying 
between human dignity as equality and human dignity as liberty, including in the context of abortion. ${ }^{128}$

In short, the future has yet to be determined. For reasons intellectual, historical, and jurisprudential, Professor Ginsburg's skillful advocacy on behalf of Captain Susan Struck warrants the careful inspection that it has long been denied. The Struck brief shows that in 1972 Ruth Bader Ginsburg viewed laws imposing traditional sex stereotypical roles on pregnant women as a core case of sex discrimination; she argued that such laws violated equal protection because they denied individual women equal opportunity and imposed on women as a group a dependent, subordinate status in American society. Haltingly but discernibly, the country is coming to adopt her perspective as its own.

ways in which judges, especially Justices, act not as "umpires" but as engaged participants in the constitutional culture of the nation).

128. For a discussion of Justice Kennedy's relevant views, see generally Siegel, supra note 82. 